\title{
A FORÇA QUE AINDA MOVE: EDUCAÇÃO DAS CRIANÇAS, CARREIRA DOCENTE E MOVIMENTO DE GREVE EM SÃO PAULO*
}

Artur Oriel Pereira

Este capítulo foi construído a partir de uma etnografia desenvolvida no contexto da educação municipal da capital de São Paulo, Brasil $^{1}$. Nele destaco a experiência com a greve municipal de 2019, que ocorreu assim que ingressei no campo de pesquisa. Partindo de algumas indagações sobre como os(as) professores(as) articulam práticas de apoio uns com os outros nos momentos de luta, como as famílias e as crianças matriculadas nas creches, pré-escolas e escolas entendem e participam ou não da greve, e como o governo reage frente às reivindicações dos(as) servidores(as) públicos(as) municipais, apresento dados referentes às manifestações e assembleias que aconteceram na região central da cidade, focando as análises na educação das crianças e na valorização da carreira docente.

Início do ano letivo e na primeira semana de aula, os(as) servidores(as) públicos municipais tiveram uma Assembleia Geral promovida pelas Entidades Sindicais. Nela foi decidida uma greve unificada contra a reforma da previdência municipal e a política de não reajuste salarial das diferentes categorias do funcionalismo público; assim várias creches, pré-escolas e escolas aderiram ao movimento de greve, inclusive, a que eu desenvolveria o campo de pesquisa.

Durante esse período, acompanhei a greve. Para tal, solicitei que os(as) professores(as) conhecidos(as) me adicionassem nos grupos do aplicativo WhatsApp ${ }^{2}$, assim ficaria sabendo a respeito das informações

\footnotetext{
*DOI - 10.29388/978-65-86678-02-4-0-f.127-148

${ }^{1}$ Parte dos resultados de uma pesquisa de mestrado que realizou um estudo interseccional sobre as práticas de amizades entre as crianças pequenas na educação infantil (PEREIRA, 2019).

${ }^{2}$ WhatsApp é uma multiplataforma de mensagens instantâneas e chamadas de voz para smartphones.
} 
por eles(as) articuladas e também participaria das manifestações e assembleias que aconteceriam no centro da cidade:

Mãos em punho, cartazes, bandeiras e faixas contornavam a paisagem local. Professores(as) municipais deixaram as creches, pré-escolas e escolas. Estavam nas ruas da região central da cidade em coro, gritando: “Revoga, já!”. Eles(as) reivindicavam a revogação da Lei Municipal no 17.020/201833, defendiam os serviços públicos de qualidade, a valorização deles(as) e dos serviços públicos. Também conclamavam toda a população do país a participarem da luta contra a Proposta de Emenda Constitucional $n^{\circ} 06 / 2019^{4}$, que atingiria todos(as) os(as) trabalhadores(as), principalmente os(as) mais pobres (Caderno de Campo, fevereiro, 2019) $)^{5}$.

Nesse contexto, convém destacar que historicamente, como elucida Vianna (1999), ao longo de sua trajetória, o movimento docente no Brasil ora se aproxima do movimento operário, quando coloca em ação um repertório de lutas, tais como greves, protestos, piquetes, ora dele se distingue, posto que guarda a especificidade do(a) trabalhador(a) do campo da educação e da cultura, ou seja, como trabalhador(a).

A pesquisadora pontua que a categoria docente se identifica com a classe trabalhadora, à medida que adquire "consciência operária", supera a alienação e se percebe como parte do trabalho assalariado, outros afirmam que o compromisso de classe "é fruto não da identificação enquanto trabalhador(a) assalariado, mas do papel de mediador assu-

\footnotetext{
${ }^{3}$ Lei que modificou o sistema previdenciário municipal. Instituiu a Previdência Privada Complementar (SAMPAPREV) e aumento o desconto da previdência do funcionalismo de $11 \%$ para $14 \%$.

${ }^{4}$ Proposta de Emenda à Constituição (PEC) que faz mudanças no Sistema Previdenciário a nível Federal.

${ }^{5}$ Inspirado na pesquisa etnográfica de Souza (2015) que abordou a infância quilombola vivida por crianças da comunidade Quilombo Brotas (Itatiba-SP), destacarei neste capítulo os trechos do caderno de campo em itálico, assim como as falas dos sujeitos dentro do contexto.
} 
mido pelo professor enquanto intelectual orgânico, com a finalidade de construir um projeto político ligado ao proletariado" (VIANNA, 2001, p. 104).

Diante da pauta de reivindicações do Fórum Unificado das Entidades Sindicais, que se constitui como representante não em uma fusão de todos(as) trabalhadores(as) na mesma classe, mas aliança entre distintos segmentos das classes trabalhadoras, que tratava dos direitos dos(as) servidores(as) públicos municipais. O expediente do governo se revelou intransigente e carregado de intimidações. Diante de qualquer reação em defesa dos direitos, o governo executou punição aos servidores. Entre essas ações, houve a aplicação de falta injustificada e o não pagamento dos dias da greve. Desrespeitando, assim, o direito de greve previsto no inciso VII do artigo 37 da Constituição Federal de 1988 e na Lei Orgânica (Constituição Municipal) ${ }^{6}$ - aprovada após a promulgação da Constituição Federal -, como referência legal, que garante o livre direito de organização sindical e negociação coletiva.

Servidores(as) municipais tiveram medo e estavam angustiados(as), porém não menos aguerridas(os) frente aos desmandos do governo. Cidadãos nos seus carros, no transporte coletivo, nas praças, nas lojas, apoiavam a causa dos(as) servidores(as). Mas também, outros os(as) acusavam: "vão trabalhar vagabundos"; "não vou pagar sua aposentadoria integral”; "não tá contente exonere"; "por que não vão protestar nos finais de semana seus baderneiros" (Caderno de Campo, fevereiro de 2019).

Nesses momentos, as condições existenciais estão evidenciadas, visíveis, refletindo o quanto a luta pela conquista de direitos e a perspectiva democrática de nossa sociedade é uma constante, tendo em vista que discursos e práticas de viés conservador e reacionário ainda estão presentes. Tais discursos acerca da luta dos servidores(as) públi-

\footnotetext{
${ }^{6}$ E ainda, a Lei $n^{\circ} 14.660 / 2007$, que dispõe sobre o Quadro dos Profissionais de Educação (QPE), que, em seu artigo 100, deixa explícito que a valorização dos servidores será assegurada, também, com o exercício do direito à livre negociação e direito de greve.
} 
$\cos$ (as) ancorados numa organização social que alimenta as subjetividades, que mimetiza espectros hostis do passado, que odeia e maltrata quem pensa diferente, quem tenta compreender o mundo social, as relações sociais, o entendimento da diferença e diversidade étnico-racial, de gênero, de idade e classe reforçam as desigualdades e os fascismos cotidianos.

Uma alarmante preocupação dos munícipes surgia em relação aos rumos que a prestação do serviço público estava tomando, sobretudo, nas áreas da Educação e da Saúde. Os(as) servidores(as) que estavam em greve, ficaram pressionados(as) pelas famílias atendidas, pelo governo intransigente, pelos(as) parceiros(as) de trabalho que não reconheciam a luta ou não se viam como trabalhadores(as) iguais, nas mesmas condições (Caderno de Campo, fevereiro de 2019).

Durante esse processo, o descaso do governo e sua injustiça não passou despercebido pelos(as) professores(as) que estavam na luta. Estes manifestaram suas indignações de diferentes formas e com pequenas doses de irreverência, por meio das redes sociais.

Com o passar dos dias, o funcionalismo público municipal nas suas várias instâncias foi aderindo gradativamente ao movimento de greve. $\mathrm{Na}$ área da Educação, inúmeras creches, pré-escolas e escolas paralisaram suas atividades educativas:

Diretores(as), assistentes de direção, coordenadores(as), professores(as) e demais profissionais da educação conversavam com as comunidades, com as diferentes famílias, e acompanhavam os desdobramentos da greve. Famílias apoiavam as reivindicações, porém uma grande parcela, não concordavam com a falta de aulas para seus(suas) filhos(as), sendo inclusive, a favor das atitudes intimidatórias do governo. Comandos de greve promovidos pelo Fórum Unificado das Entidades Sindicais foram realizados em diversos pontos da cidade (Caderno de Campo, fevereiro de 2019). 
Nas manifestações e assembleias no centro da cidade não havia a presença efetiva de famílias com as crianças, mas essa presença ocorreu em outras regiões. Na oitava manifestação na região central, contudo, houve uma participação significativa de mães e pais de crianças matriculadas nas creches, pré-escolas e escolas municipais.

Apoiando a causa dos(as) professores(as), eles(as) idealizaram e organizaram um evento nomeado "Ouve as Crianças, Prefeito!". As famílias junto com seus(suas) filhos(as) convidavam as pessoas no local para participarem de uma ciranda pela educação. Entoando cantigas de roda e conversando com as pessoas, eles(as) alertavam que a Educação municipal estava passando por um processo de sucateamento e, sendo assim, todos(as) precisavam lutar por qualidade e garantias para a educação pública, bem como para que as crianças pudessem voltar às suas atividades educativas.

Entre as cantigas de roda, destaco uma delas, a mais cantada por diversas vezes:

Quando a lua chega de onde mesmo que ela vem?

Quando a gente nasce já começa a perguntar

Quem sou?

Quem é?

Onde é que estou?

Mas quando amanhece quem é que acorda o sol?

Quando a gente acorda já começa a imaginar

Pra onde é que eu vou?

Qual é?

No que é que isso vai dar?

Quando a estrela acende ninguém mais pode apagar

Quando a gente cresce tem um mundo pra ganhar

Brincar, dançar, saltar, correr

Meu deus do céu onde é que eu vim parar?

Quando a lua chega de onde mesmo que ela vem?

Quando a gente nasce já começa a perguntar 
Quem sou?

Quem é?

Onde é que estou?

Mas quando amanhece quem é que acorda o sol?

Quando a gente acorda já começa a imaginar

Pra onde é que eu vou?

Qual é?

No que é que isso vai dar?

Quando a estrela acende ninguém mais pode apagar

Quando a gente cresce tem um mundo pra ganhar

Brincar, dançar, saltar, correr

Meu deus do céu onde é que eu vim parar?

Brincar, dançar, saltar, correr

Meu deus do céu onde é que eu vim parar?

As crianças pequenininhas que estavam nos colos de suas mães e seus pais, as crianças pequenas e maiores alegremente cantavam e dançavam em movimento circulares, formando uma grande ciranda, esta canção intitulada Sol, Lua e Estrela, do compositor Paulo Tatit (2005), tocada pelo grupo musical Palavra Cantada, é uma música presente no cotidiano da Educação Infantil e conhecida por todos(as) que ali estavam.

Esse tipo de evento apareceu em outras greves ligadas à educação. Como aponta Macedo (2016, p. 29), em pesquisa sobre a participação de crianças de 0 a 3 anos que, entre outras questões, discute a respeito da organização das passeatas na Universidade de São Paulo (USP):

O movimento grevista da Universidade de São Paulo tem, ao longo dos anos, acumulado a experiência de participação das crianças e bebês em suas atividades. Muitas das crianças vêm diariamente junto com seus/suas pais/mães, na ida e volta do trabalho, pois frequentam as creches no campus e, assim, durante o 
período de paralisação, acompanham suas mães e/ou seus pais em assembleias, piquetes e demais atividades organizadas pelo coletivo de trabalhadores/as. Aos poucos, a participação das crianças chamou a atenção do sindicato e de seus membros que foram planejando espaços que possibilitassem maior conforto para que elas não ficassem entediadas ou aborrecidas por terem de esperar enquanto o pai e/ou a mãe participavam de atividades "adultas". Nos momentos em que se reuniam para confeccionar as faixas que levariam a público as reivindicações do movimento ou que expressariam as críticas aos que deferiam ataques à classe trabalhadora, logo apareciam as crianças interessadas e ansiosas em brincar com os pincéis, tintas e papéis. Muitas participavam preenchendo com tinta as grandes letras desenhadas pelos/as adultos/as. Ou aproveitando para explorar os materiais artísticos como: papéis, tintas, barbantes, fitas adesivas etc. Assim, em algumas ocasiões, em diferentes anos em que houve paralisação, o comando de greve passou a organizar "cantinhos das crianças", brincadeira em frente à reitoria ocupada, "cirandas" etc. Algumas destas atividades eram planejadas pelas professoras das creches, sensibilizadas pelos pedidos das crianças que queriam encontrar os amigos para brincar.

No interior da greve municipal de 2019, também emergiu uma rede de solidariedade entre os(as) profissionais da educação, que reuniu pessoas de todas as Diretorias Regionais de Educação (DRE), situação esta que permitiu um pouco de resgate da força e da dignidade, um movimento que foi dinamizado pela cooperação e pelo trabalho comunitário. Procurando enfrentar as dificuldades, eles(as) se organizavam e formavam parcerias com apoio psicológico e financeiro, de tal sorte que professores(as) da mesma escola, podiam contar com a ajuda dos(as) demais professores(as) para resistir às opressões:

Nas tramas dessa rede composta também com a participação de entidades sindicais, centrais sindicais e servidores(as) que tinham aderido à greve, e até mesmo a participação por parte de pessoas físicas e jurídicas solidárias ao movimento em defesa 
dos serviços e dos direitos dos(as) servidores(as). Foi posto em discussão na $7^{\text {a }}$ Assembleia critérios para a aprovação e a captação de recursos e divisão do Fundo de Greve ${ }^{7}$, para a aqueles(as) que tivessem seus rendimentos salariais descontados, pudessem manter parte dos seus sustentos (Caderno de Campo, fevereiro de 2019).

O governo demorou a dialogar, fugiu das discussões, divulgou inverdades, mandou cortar o ponto dos(as) servidores(as) e desmarcou reuniões agendadas. E nesse cenário, foi se construindo uma divisão das categorias que já estava esgotada. A exaustão abatia a todos(as), algo que é próprio de toda luta, pois assim foi encarada a situação pelos(as) grevistas. Uma luta de classes cujos oponentes em sua máxima crueldade nos seus gabinetes ou nas mídias emitiam mensagens que ordenavam o encerramento, afirmando: "Eu não vou tratar igual quem trabalha e quem não trabalha" ${ }^{\text {. }}$.

Com isso, muitos(as) servidores(as) sequer viram o salário no fim do mês. Tiveram contas atrasadas, telefonemas de cobrança e redução do sustento. Mesmo assim, eles(as) resistiram:

Nas manifestações, tiveram dias que tinham 100 mil pessoas, noutro 80 mil, caindo para 20 mil, subindo para 50 mil, descendo para 15 mil. Servidores(as) foram se revezando, um(a) caia ali e outro(a) segurava ali. Um(a) professor(a) avisava: "hoje não posso ir", o(a) outro(a) que não tinha comparecido(a), dizia: "estou indo com vocês". E assim, seguiam todos(as) naquela tensão. Ficavam em pé longas horas, se protegiam da chuva, dos raios do Sol nas ruas da cidade. Eles(as) mudaram suas rotinas, correram atrás do assaltante que roubavam seus celulares. Fizeram longas caminhadas pelas ruas, se esquivaram para o carro não avançar e

\footnotetext{
${ }^{7}$ Com o tempo, o Fundo de Greve do Fórum Unificado das Entidades Sindicais não se concretizou, ficou somente no campo das discussões.

${ }^{8}$ Em entrevista, o Prefeito de São Paulo Bruno Covas (PSDB). Disponível em: $<\underline{\text { https://jovempan.uol.com.br/programas/panico/nao-tem-sentido-a-prefeitura-sub- }}$ sidiar-uma-obrigacao-do-patrao-diz-covas-sobre-mudanca-no-bilhete-unico.html.> Acesso em: 24 jul. 2019.
} 
passar por cima. Se protegeram da naturalizada opressão e agressão policial. Socorreram os(as) amigos(as), receberam apoio, deram apoio (Caderno de Campo, março de 2019).

Durante esses dias, a sensação era de estar em um mundo paralelo, de um lado a efervescência de acontecimentos, e, de outro o fluxo familiar da metrópole. Passava o rapaz de jaleco correndo de um lado. Passava a moça com o celular no ouvido andando apressadamente. Enquanto isso, muitos(as) aguardavam um diálogo com o governo, torcendo para que ocorresse o reconhecimento da greve.

A preocupação dos(as) professores(as) com seu trabalho docente foi posta do início até o fim da greve. Conversando com as pessoas nas ruas, eles(as) ressaltavam que a resistência aos atos do governo era necessária. Ao contrário, o governo com os discursos que não condiziam com as práticas, as muitas declarações que elegiam a educação como prioridade para o desenvolvimento de uma sociedade digna, ficaram somente em palavras discursadas em palanques de campanha política.

A repercussão desses acontecimentos e de outros ligados à gestão pública municipal não foram favoráveis para o atual governo, que enfrentava uma grande percentagem de reprovação por partes dos(as) paulistanos. Segundo o Instituto Paraná Pesquisas (2019), 35\% dos munícipes avaliavam a gestão da Prefeitura de São Paulo como regular, enquanto $16,7 \%$ consideram ruim e $25,4 \%$ péssima. Apenas, $17,3 \%$ avaliam como boa e $2,9 \%$ apontam como ótima ${ }^{9}$.

Aqui, cabe destacar que o Estado não dispõe de um poder plenamente autônomo, pois ele é a expressão das contradições entre o mercado (interesses privados) e o Estado (interesses comunitários/da coletividade) numa sociedade de classes. Nesse sentido, como alertam Marx \& Engels (1982, p. 24-25), na ideologia alemã:

\footnotetext{
${ }^{9}$ Pesquisa sobre a administração do Prefeito de São Paulo. Instituto Paraná Pesquisas. Disponível em: <https://www.paranapesquisas.com.br/noticias/o-reacionariodivulga-pesquisa-realizado-pela-parana-pesquisas-sobre-a-administracao-doprefeito-de-sao-paulo-bruno-covas/.> Acesso em: 22 jul. 2019.
} 
E é precisamente por esta contradição do interesse particular e do interesse comunitário que o interesse comunitário assume uma forma autônoma como o Estado, separado dos interesses reais dos indivíduos e de todos, e ao mesmo tempo como comunidade ilusória, mas sempre sobre a base real dos laços existentes em todos os conglomerados de famílias e tribais [...], e especialmente, como mais tarde desenvolveremos, das classes desde logo condicionadas pela divisão do trabalho e que se diferenciam em todas as outras. Daqui resulta que todas as lutas no seio do Estado, a luta entre a democracia, a aristocracia e a monarquia, a luta pelo direito de voto, etc., etc., não são mais do que formas ilusórias em que são travadas as lutas reais das diferentes classes entre si [...]; e também que todas as classes que aspiram o domínio, mesmo quando o seu domínio, como é o caso com o proletariado, condiciona a superação de toda forma velha da sociedade e da dominação geral, têm primeiro de conquistar o poder político, para por sua vez representarem o seu interesse como o interesse geral, coisa que no primeiro momento são obrigações a fazer.

Assim, a classe trabalhadora dos(as) servidores(as) públicos municipais em luta pelos seus direitos trabalhistas conquistados, que "lotavam o metrô" em dia de manifestação, que "atrapalhavam o trânsito", que tinham parentes morrendo e nascendo, tinham filhos(as) que estavam sem aulas ou que deixaram de ir, que enfrentavam o divórcio, o câncer, a depressão ou a dificuldade financeira.

Historicamente, eles(as) estavam no mesmo Brasil do golpe do impeachment de 2018, da democracia fragilizada, da grave recessão econômica, do desmando dos poderosos, do desmonte dos serviços públicos em benefício da classe mais abastada e sempre privilegiada.

Como elucida Fornazieri (2019), na análise da longa crise brasileira:

A crise política veio acompanhada por dois anos de grave recessão econômica e por anos continuados de baixo crescimento, baixo investimento público e privado, alto desemprego e elevada 
dívida pública. A crise de coordenação política nacional se reflete também na economia e na sociedade. [...] O golpe do impeachment, a radicalização da Lava Jato, a avalanche de denúncias de corrupção as inúmeras prisões de agentes políticos e partidários e, finalmente, a prisão de Lula e o fracasso do governo Temer, colapsaram, primeiro, o PT; depois, o atual MDB e, finalmente, o PSDB. Assim, se abriu o espaço para o fortalecimento de uma força política secundária entre as existentes ou para o surgimento de uma nova força. A sociedade escolheu a última opção, através de Bolsonaro. [...] A crise política, desta forma, vai se mantendo e prolongando a agonia do Brasil e de seu povo. É uma crise de organização das forças políticas partidárias e uma crise de liderança. É uma crise de capacidade de coordenação e de condução do país. É uma crise de força política. Sem partidos fortes e sem lideranças fortes não há capacidade de coordenação, de aglutinação das forças dispersas e fragmentadas. Partidos e líderes fracos resultam em governos fracos, em fracassos políticos e administrativos ${ }^{10}$.

Neste contexto, os(as) servidores(as) públicos(as) municipais em greve são parte de uma sociedade fundada no patriarcado e no feminicídio, que pratica, diariamente, o racismo e a intolerância religiosa. A sociedade dos massacres indígenas, dos alagamentos, incêndios e privatizações; dos parlamentares com suas laranjas e goiabas, dos liquidificadores pintados de rosa ou azul, da Vale com sua lama tóxica. Um país da desigualdade social, onde a fome e a seca, a corrupção e a ânsia pelo porte de armas aos civis, o desejo em criminalizar movimentos sociais e a avalanche de notícias falsas tidas como verdades absolutas percorrem o cotidiano.

\footnotetext{
${ }^{10}$ A longa crise brasileira, por Aldo Fornazieri. GGN-O Jornal de Todos os Brasis.

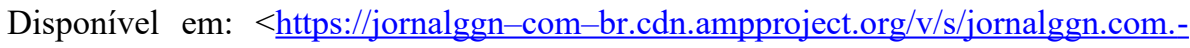
br/artigos/a-longa-crise-brasileira-por-aldo-fornazieri/amp/? usqp=mq331AQA\&amp js $v=0.1 \#$ aoh $=15638818460081 \& a m p \_c t=156388185108$ $7 \&$ referrer $=\mathrm{https} \% 3 \mathrm{~A} \% 2 \mathrm{~F} \% 2 \mathrm{Fwww}$.google.com\&amp tf=Fonte $\% 3 \mathrm{~A}$ $\% 20 \% 251 \% 24$ s\&ampshare $=$ https $\% 3 \mathrm{~A} \% 2 \mathrm{~F} \% 2 \mathrm{Fjornalggn}$.com.br $\% 2 \mathrm{Fartigos} \% 2 \mathrm{Fa}-$ longa-crise-brasileira-por-aldo-fornazieri\%2F. > Acesso em: 24 jul. 2019.
} 
A ação coletiva dos(as) professores(as) militantes, como destaca Gallo (2002, p. 171), vivencia as misérias da situação social da qual eles(as) participam em diversos ângulos e em diversos níveis. "Essa militância, que é ao mesmo tempo uma militância que se dá em sala de aula, que se dá no local de trabalho, que se dá na relação com o sindi cato, ou seja, na relação da sua classe produzindo cultura, produzindo política, produzindo educação fundamental”, impulsiona a produção de condições de superação das misérias e cria possibilidades de libertação. De encontro com a perspectiva de bell hooks (2013, p. 273), "n esse campo de possibilidades temos a oportunidade de trabalhar pela liberdade, de exigir de nós e dos outros camaradas uma abertura de mente e de coração que nos permita encarar a realidade ao mesmo tempo em que, coletivamente, imaginamos esquemas para cruzar fronteiras, para transgredir".

Nesse sentido, assumindo a condição de professor militante e pesquisador, levanto algumas inquietações: tão óbvio e tão difícil fazer as pessoas entenderem que o lugar agora é nas ruas? Que o momento é histórico e único? Que o desmonte dos direitos trabalhistas brasileiros estão a todo vapor, e que é possível barrar? Que é preciso indignar-se e gritar, que não se pode aceitar o que já bradaram realizar?

Com base nas ações da classe trabalhadora suscitada no conto "Primeiro de maio", publicado no livro póstumo Contos Novos ${ }^{11}$, de Andrade (1983), na qual propõe uma data para a ação política da classe operária e que rememora aspectos da história da luta de classes vinculada ao Dia Internacional do Trabalhador. Que os(as) trabalhadores(as) consigam, de tal sorte, poeticamente inspirados(as) no conflito de um jovem operário, identificado como "chapinha 35", experimentar reflexões e emoções que irão da felicidade matinal à amargura e desencanto vespertinos, mesmo assim, estes sentimentos, quem sabe, poderão acalentar a esperança de que no futuro haja liberdade democrática para que tanto essa data comemorada internacionalmente quanto os dias de

11 A obra marca o contexto histórico-cultural do Estado Novo no Brasil, precisamente em São Paulo, capital e interior, nas décadas de 1920 a 1940 imerso no processo de urbanização e industrialização (cidade), patriarcalismo versus progressismo (ambiente rural). 
reivindicações de direitos trabalhistas organizados nas ruas das cidades brasileiras sejam reconhecidos sem repressão.

A força que ainda move as pessoas para a luta surge daquilo que sentimos quando estamos juntos(as), bem como aquela emoção que sentimos quando vemos a multidão que foge ao alcance dos olhos, surge quando todos(as) estão unidos(as) em uma só voz. Seguindo fortes e apoiados(as) uns nos outros, assim, resistiam os(as) servidores(as) públicos(as) municipais trinta e três dias de greve, com nove assembleias gerais unificadas e três reuniões de negociação com o governo, permeadas por manifestações e passeatas na região central da cidade. O desejo de eternizar esse momento ou captá-lo, de modo que, oferecesse aos olhos e aos corações daqueles(as) que por diversos motivos não estavam ali presentes se materializa.

Quadro 1 - Dados da Greve das(os) servidores(as) municipais de 2019

\begin{tabular}{|c|c|}
\hline $\begin{array}{c}\text { 1a Manifestação e } \\
\text { Assembleia Geral } \\
\text { Unificada }\end{array}$ & $\begin{array}{l}\text { - A pauta pede a revogação da Lei } 17.020 / 18 \text { da Sam- } \\
\text { paprev; o fim da política salarial de } 0,01 \% \text { e reajuste } \\
\text { geral de } 10 \% \text { para todos os servidores municipais ati- } \\
\text { vos e aposentados da cidade. } \\
\text { - Prefeitura não se manifesta; } \\
\text { - Aprovada Greve Unificada; }\end{array}$ \\
\hline $\begin{array}{c}2^{\text {a }} \text { Manifestação e } \\
\text { Assembleia Geral } \\
\text { Unificada }\end{array}$ & $\begin{array}{l}\text { - Prefeitura não se manifesta. } \\
\text { - Passeata dos(as) servidores(as) municipais segue até } \\
\text { o MASP - Museu de Arte de São Paulo Assis Chateau- } \\
\text { briand, na Avenida Paulista, onde foi encerrada. } \\
\text { - A Greve Unificada continua; }\end{array}$ \\
\hline $\begin{array}{c}3^{\text {a }} \text { Manifestação e } \\
\text { Assembleia Geral } \\
\text { Unificada }\end{array}$ & $\begin{array}{l}\text { - Servidores municipais e Fórum Unificado das enti- } \\
\text { dades sindicais mantêm suas reivindicações; } \\
\text { - Prefeitura não se manifesta; } \\
\text { - A Greve Unificada continua. }\end{array}$ \\
\hline $\begin{array}{c}4^{\text {a }} \text { Manifestação e } \\
\text { Assembleia Geral } \\
\text { Unificada }\end{array}$ & $\begin{array}{l}\text { - Servidores municipais e Fórum Unificado das enti- } \\
\text { dades sindicais mantêm suas reivindicações; } \\
\text { - Prefeitura aplica falta injustificada e o não pagamen- } \\
\text { to dos dias de greve; }\end{array}$ \\
\hline
\end{tabular}




\begin{tabular}{|c|c|}
\hline & - A Greve Unificada continua. \\
\hline $\begin{array}{c}5^{a} \text { Manifestação e } \\
\text { Assembleia Geral } \\
\text { Unificada }\end{array}$ & $\begin{array}{l}\text { - Encontro mensal dos parlamentares com a Prefeitu- } \\
\text { ra que comparece à Câmara Municipal para tratar das } \\
\text { questões do município; } \\
\text { - Vereadores entregam a Prefeitura mais uma vez a } \\
\text { pauta de reivindicação do Fórum Unificado das enti- } \\
\text { dades sindicais dos servidores públicos municipais em } \\
\text { greve; } \\
\text { - Vereadores cobram a Prefeitura para que abra espa- } \\
\text { ço à negociação e diálogo com os milhares de servido- } \\
\text { res com vistas ao tratamento das suas reivindicações; } \\
\text { - Vereadores reapresentam a Prefeitura a tabela de } \\
\text { vencimentos dos profissionais de Educação para des- } \\
\text { tacar o salário inicial de professor em Jornada Básica } \\
\text { Docente e do profissional do Quadro de Apoio à Edu- } \\
\text { cação no início da carreira; } \\
\text { - Servidores municipais e Fórum Unificado das enti- } \\
\text { dades sindicais decidem unir-se a CUT- Força Sindi- } \\
\text { cal, CTB, Intersindical, Nova Central, CGTB, CSP- } \\
\text { Conlutas e CSB em Assembleia Nacional da Classe } \\
\text { Trabalhadora contra a PEC 06/19 (Proposta de Emen- } \\
\text { ta Constitucional) da previdência Federal; } \\
\text { - A Greve Unificada continua. }\end{array}$ \\
\hline $\begin{array}{c}\text { 6a Manifestação e } \\
\text { Assembleia Geral } \\
\text { Unificada } \\
\text { 1a Reunião de Ne- } \\
\text { gociação com o Go- } \\
\text { verno }\end{array}$ & $\begin{array}{l}\text { - Prefeitura recebe Fórum Unificado das entidades } \\
\text { sindicais em reunião, em resposta as reivindicações } \\
\text { dos servidores municipais; } \\
\text { - Prefeitura não revoga a Lei } 17.020 / 18 \text { - Sampaprev, } \\
\text { justifica que a PEC } 02 / 19 \text { replica o que foi realizado no } \\
\text { município; } \\
\text { - Prefeitura declara que qualquer discussão sobre a lei } \\
\text { só será feita com os servidores municipais após a } \\
\text { aprovação da PEC no âmbito federal; } \\
\text { - Prefeitura decide que vinculará a política de revisão } \\
\text { salarial e nova lei salarial à política de alcance de me- } \\
\text { tas - Meritocracia, com remuneração variável de até } \\
2,4 \text { salários adicionais ao ano, pagos proporcional- }\end{array}$ \\
\hline
\end{tabular}




\begin{tabular}{|c|l|}
\hline & $\begin{array}{l}\text { mente ao atingimento das metas instituídas no Pro- } \\
\text { grama de Metas e pactuadas com as Secretarias; }\end{array}$ \\
- Prefeitura só reconhece o direito de greve, mediante \\
solicitação individual ao RH pelo servidor em greve, e \\
as faltas decorrentes da greve não serão passíveis de \\
sanções, disciplinares desde que justificadas pelo ser- \\
vidor; \\
- Prefeitura aceita discussão da reestruturação das \\
carreiras de servidores, priorizando as que não tive- \\
ram reajuste nos últimos anos e restabelecer as mesas \\
de negociação com todas as carreiras, desde que a gre- \\
ge termine; \\
geciação com o Go- \\
verno
\end{tabular}









\begin{tabular}{|c|c|}
\hline & $\begin{array}{l}\text { dades sindicais, centrais sindicais e pelos servidores } \\
\text { municipais que tenham aderido ou não à greve, e até } \\
\text { mesmo, pela participação por parte de pessoas físicas e } \\
\text { jurídicas solidárias ao movimento em defesa dos ser- } \\
\text { viços e dos servidores públicos municipais; } \\
\text { - A Greve Unificada continua. }\end{array}$ \\
\hline $\begin{array}{c}\text { 8 }^{\text {a }} \text { Manifestação e } \\
\text { Assembleia Geral } \\
\text { Unificada }\end{array}$ & $\begin{array}{l}\text { - Uma parcela dos servidores municipais tem falta in- } \\
\text { justificada apontadas na folha de ponto e recebem } \\
\text { descontos dos dias da greve nos seus rendimentos re- } \\
\text { muneratórios; } \\
\text { - Prefeitura marca reunião com o Fórum Unificado } \\
\text { das entidades sindicais, porém desmarca quatro horas } \\
\text { antes do horário confirmado, adiando para data não } \\
\text { anunciada; } \\
\text { - Mães e pais de bebês e crianças que são atendidas } \\
\text { nas creches, pré-escolas e escolas municipais apoiam a } \\
\text { causa dos(as) servidores(as) municipais, apontam que } \\
\text { a educação está em processo de sucateamento. Assim, } \\
\text { idealizam e organizam o Evento "Ouve as Crianças } \\
\text { Prefeito!", que convida as pessoas no local da manifes- } \\
\text { tação a participarem de uma ciranda pela educação } \\
\text { com a presença deles(as) com suas filhas e filhos, ou- } \\
\text { tras crianças e adultos, tendo como objetivo a luta por } \\
\text { qualidade e garantias para a educação pública e para } \\
\text { que as crianças possam voltar à sua rotina escolar ime- } \\
\text { diatamente; } \\
\text { - Servidores(as) municipais e Fórum Unificado das } \\
\text { entidades sindicais mantêm suas reivindicações e de- } \\
\text { cidem pela suspensão dos cursos de Formação Cidadã } \\
\text { na Quarta-feira de Cinzas; } \\
\text { - Passeata dos servidores municipais segue até o } \\
\text { MASP - Museu de Arte de São Paulo Assis Chateau- } \\
\text { briand, na Avenida Paulista, para se unir com o movi- } \\
\text { mento dos professores da rede particular; } \\
\text { - Professoras e professores das escolas particulares, } \\
\text { em Assembleia com a entidade sindical, }\end{array}$ \\
\hline
\end{tabular}




\begin{tabular}{|c|c|}
\hline & $\begin{array}{l}\text { - Vereador idealiza e organiza o Festival "Ninguém } \\
\text { Solta a Mão de Ninguém”, gratuito, como slogan "Uni- } \\
\text { dade e solidariedade fermentam a luta dos servidores } \\
\text { públicos em greve contra a retirada de direitos em São } \\
\text { Paulo", no Teatro de Teatro de Contêiner Mungunzá, } \\
\text { na Santa Ifigênia. O festival, contou com a participação } \\
\text { de artistas, grupos de dança, poetas, apresentações } \\
\text { musicais que se somam à luta em defesa da cidade e } \\
\text { contra o desmonte dos serviços essenciais como Saúde } \\
\text { e Educação; } \\
\text { - A Greve Unificada continua. }\end{array}$ \\
\hline $\begin{array}{c}\text { 9a Manifestação e } \\
\text { Assembleia Geral } \\
\text { Unificada } \\
\text { 3a Reunião de Ne- } \\
\text { gociação com o Go- } \\
\text { verno }\end{array}$ & $\begin{array}{l}\text { - Prefeitura apresenta compromisso formal de não } \\
\text { instituição de índice de contribuição superior aos } 14 \% \text {, } \\
\text { caso a Reforma da Previdência Nacional seja aprovada } \\
\text { com a contribuição extraordinária prevista no projeto } \\
\text { Federal que permite até } 22 \% \text { de desconto; } \\
\text { - Prefeitura propõe que não haverá migração dos(as) } \\
\text { servidores(as) que ingressaram até da aprovação da } \\
\text { Sampaprev, eles(as) continuam vinculados ao Instituto } \\
\text { de Previdência Municipal (IPREM), o teto salarial } \\
\text { continua sendo superior ao do Instituto Nacional de } \\
\text { Seguro Social (INSS). Para os(as) servidores(as) que } \\
\text { ingressaram depois da lei, não serão obrigados a mi- } \\
\text { grar para a Sampaprev, o que ultrapassar o teto do } \\
\text { INSS terá o desconto se o(a) servidor(a) assim optar, } \\
\text { ressaltando que é muito importante esta manutenção } \\
\text { dos(as) servidores(as) novos(as) até o limite do INSS, } \\
\text { pois ajudarão a manter a aposentadoria dos que irão } \\
\text { se aposentar; } \\
\text { - Prefeitura dá a garantia do pagamento do piso da } \\
\text { Educação: reajuste salarial anual para a categoria; tam- } \\
\text { bém garante a mesa negocial em abril para já em maio } \\
\text { ser aplicado; } \\
\text { - Prefeitura garante pagamento de abono salarial } \\
\text { emergencial para agentes de apoio e agentes de políti- } \\
\text { cas públicas, até que seja estruturada a carreira do }\end{array}$ \\
\hline
\end{tabular}




\begin{tabular}{|l|l|}
\hline quadro de apoio, com apresentação de plano de cargos \\
e carreiras; \\
- Prefeitura garante mesas em abril para rever carrei- \\
ras do quadro de apoio, do nível superior, da saúde; \\
- Prefeitura garante pagamento dos dias parados, em \\
até 7 dias úteis dos que foram descontados, como do- \\
cumento na folha de todos(as) que foram descontados \\
e não em folha suplementar, com o reconhecimento de \\
nosso direito de greve; \\
- Fórum Unificado das entidades sindicais se posicio- \\
nam a favor da suspensão da greve, reafirmando que \\
não é o fim da greve e que podem retomar a qualquer \\
momento; \\
- Algumas categorias, como a dos(as) engenheiros(as), \\
colocaram que não conseguiam manter seus(suas) tra- \\
balhadores(as) na luta; \\
- A categoria dos(as) professores(as), historicamente \\
de luta, não estava na greve em sua capacidade máxi- \\
ma, muitos professores(as) já estavam trabalhando, in- \\
clusive nas datas das Assembleias; \\
- Em Assembleia servidores(as) aprovam a suspensão \\
da greve; \\
- Passeata dos(as) servidores(as) municipais segue até \\
o MASP - Museu de Arte de São Paulo Assis Chateau- \\
briand, na Avenida Paulista, para encontrar com o \\
Movimento Feminista e Movimento de Mulheres em \\
luta contra o feminicídio, a violência contra as mulhe- \\
res, a desigualdade de gênero no Dia Internacional da \\
Mulher.
\end{tabular} \mid

Fonte: Quadro elaborado pelo autor (2019).

\section{Referências}

GALLO, Sílvio. Em torno de uma educação menor. Educação \& Realidade. v. 27, n. 2, p. 169-178, jul./dez. 2002. 
HOOKS, Bell. Ensinando a transgredir: a educação como prática da liberdade. Trad. Marcelo Brandão Cipolla. São Paulo: Editora WMF Martins Fontes, 2013.

MACEDO, Elina Elias de. Crianças pequenininhas e a luta de classes. 135f. Tese (Doutorado em Educação). Faculdade de Educação. Programa de Pós-graduação em Educação, Campinas, SP, 2016.

MARX, Karl; ENGELS, Friedrich. Feuerbach: Oposição das concepções materialistas idealista (Capítulo Primeiro de A Ideologia Alemã). In:

. Obras escolhidas em três tomos (Tomo I). Edições Avante: Lisboa/ Edições Progresso/Moscou, 1982.

PEREIRA, Artur Oriel. 'Você quer ser meu amigo?”: um estudo interseccional das práticas de amizade entre as crianças pequenas na educação infantil. 138f. Relatório de Qualificação (Mestrado em Educação). Programa de Pós-Graduação em Educação. Faculdade de Educação. Universidade Estatual de Campinas, Campinas, 2019.

SÃO PAULO (SP). Lei No 17.020 de 27 de Dezembro de 2018. Regime de Previdência Complementar. Disponível em: $<$ http://legislacao.prefeitura.sp.gov.br/leis/lei-17020-de-27-de-dezembro-de-2018 > Acesso em: 25 fev. 2019.

Decreto ${ }^{\circ}$ 57.557, de 21 de Dezembro de 2016. Regulamenta a Lei no 15.939, de 23 de dezembro de 2013. Disponível em: < $\underline{\text { http://le- }}$ gislacao.prefeitura.sp.gov.br/leis/decreto-57557-de-21-de-dezembrode-2016>Acesso em: 02 jun. 2019.

. Lei No 0 de 4 de Abril de 1990. Lei Orgânica do Município de São Paulo. Disponível em: <http://legislacao.prefeitura.sp.gov.br/leis/ lei-0-de-04-de-abril-de-1990> Acesso em: 25 fev. 2019.

. Lei no 14660 de 26 de Dezembro de 2007. Reorganiza O Quadro dos Profissionais de Educação, com as Respectivas Carreiras, e Consolida O Estatuto dos Profissionais a Educação Municipal. Disponível em: <https://www.radarmunicipal.com.br/legislacao/lei-14660> Acesso em: 25 fev. 2019. 
VIANNA, Cláudia. A produção acadêmica sobre organização docente: ação coletiva e relações de gênero. Educação \& Sociedade, Campinas, no 77, p. 100-130, dez. 2001.

. Os nós dos “nós”. Crise e perspectivas da ação coletiva docente em São Paulo. São Paulo: Xamã, 1999. 
